\title{
GENETIC STABILITY AND DIVERSITY IN YIELD COMPONENTS OF SOME WHEAT GENOTYPES THROUGH SEASONS AND HEAT STRESS UNDER DIFFERENT LOCATIONS
}

\author{
Hamam, K. A. ${ }^{1}$, A. G. A. Khaled ${ }^{2}$ and M. M. Zakaria ${ }^{3}$ \\ ${ }^{1}$ Department of Agronomy, Faculty of Agriculture, Sohag University, \\ 82524 Sohag, Egypt \\ ${ }^{2}$ Department of Genetics, Faculty of Agriculture, Sohag University, \\ 82524 Sohag, Egypt \\ ${ }^{3}$ Field Crops Research Institute, Agricultural Research Center, Egypt \\ E-mail: khalafhamam@agr.sohag.edu.eg
}

\begin{abstract}
Genetic stability and diversity are two of the key factors for the improvement of many crop plants. A major challenge for plant breeders is selection of high yielding genotype with wide adaptation. Therefore, thirty six wheat genotypes were evaluated under two locations (Sohag and Aswan, Egypt) on favorable and late sowing date during winter seasons of 2012/2013 and 2013/2014 to estimate its performance and stability parameters. The wide range of weather conditions resulted in a broad variation of mean yields, ranging from $6.59 \mathrm{t} / \mathrm{ha}$ in favorable sowing date to $4.99 \mathrm{t} / \mathrm{ha}$ in late sowing date as heat stress. The combined analysis of variance showed that the flag leaf area, days to heading, spike length, 1000-kernel weight and grain yield were significantly influenced by years, locations, sowing dates and genotypes. Mean environmental grain yield ranged from $2.70 \mathrm{t} / \mathrm{ha}$ to $9.27 \mathrm{t} / \mathrm{ha}$. The results showed that sowing at the favorable date increased all studied traits. The 36 genotypes showed diversity for the slopes of the joint regression. Genotypes No. 5, 6, 14, 19, 20, 22, 24 and 32 exhibited stability for grain yield and useful in the breeding program in developing new wheat genotypes with tolerance to heat stress conditions. Positive correlation was found between $b_{i}$ and $\bar{x}$ for days to heading, spike length, number of kernels/spike, 1000-kernel weight and grain yield $\left(0.89^{* *}, 0.50^{* *}, 0.07,0.13\right.$ and $\left.0.51^{* *}\right)$, respectively. This might be due to adaptation of these genotypes to wide differences in climatic conditions which prevailed at the two studied locations. The best genotypes in terms of both favorable and heat stress indicating that selecting for improved yield potential may increase yield in wide range of environments.
\end{abstract}

Keywords: wheat (Triticum aestivum L.), genotypes, stability, locations, sowing date, years.

\section{INTRODUCTION}

Increasing in crop yields are important to ensure food supply for humanity (Rondanini et al. 2012). Terminal heat is a major abiotic stress affecting yield in wheat. Under heat stress, the photosynthetic process is affected especially during grain filling stage when demand for assimilates is the greatest (Kumari et al. 2007). Stay-green character is an important trait that allows plants to retain their leaves in active photosynthetic under stress conditions (Rosenow et al. 1983). In the rice-wheat cropping system, crop damage due to heat stress under late planting conditions has become an important factor limiting wheat yields (Aslam et al. 1989). High temperatures during early crop development and particularly after anthesis may limit yield (Hunt et al. 1991). Temperature fluctuations during grain filling were found to 
cause deviations from expected dough properties (Blumenthal et al. 1991). The rise in daily average temperature, up to about $30^{\circ} \mathrm{C}$, increased dough strength, while temperatures above this threshold value $(35-40 \stackrel{\circ}{\circ})$, even for periods of only few days, tended to decrease dough strength (Randall and Moss 1990; Corbellini et al. 1997). Mondal et al. (2013) suggested that the early maturing, high yielding, and heat tolerant wheat lines developed in Mexico can adapt to the diverse heat stressed area. The phenotypic performance of a genotype is not necessarily the same under diverse agroecological conditions (Ali et al. 2003). Genotype-environment (GE) interactions are extremely important in the development and evaluation of genotypes because it reduce the genotypic stability values under diverse environments (Hebert et al. 1995).

The concept of stability was defined in several ways and several biometrical methods including univariate and multivariate ones (Crossa 1990). The most widely used method is the regression way, which is based on regressing the mean value of each genotype on the environmental index or marginal means of environments (Tesemma et al. 1998). A good method for measuring stability was previously proposed (Finlay and Wilkinson 1963) and was later improved (Eberhart and Russell 1966). The stable variety was defined by a high mean yield, regression coefficient $\left(b_{i}=1.0\right)$ and the deviations from regression as small as possible $\left(S^{2} d_{i}=0\right)$. In addition, the stability was defined as adaptation of varieties to unpredictable and transient environmental conditions and the technique has been used to select stable genotypes unaffected by environmental changes (Allard and Bradshaw 1964).

Musich and Dusek (1980) found a decrease in grain yield by delaying sowing date. Dessouki et al. (1974) reported that the optimum date of wheat sowing was mid-November in Lower Egypt and 10 days later in Upper Egypt. Spring wheat grain yield and its components were reported to be more closely associated with temperature variation according to locations than with variation in transpiration (Saadalla 1993).

Therefore, the objective of this study is to estimate the stability parameters of thirty six wheat genotypes under six environments (two sowing dates, two locations and two years) for selecting widely adapted genotypes.

\section{MATERIALS AND METHODS}

\section{Planting and treatments:}

Thirty six wheat genotypes were evaluated for its performance and stability parameters in the field under normal irrigated conditions. A set of 36 bread wheat genotypes (Table 1) were classified as: No.1 to No.34 genotypes were obtained from the International Maize and Wheat Improvement Center (CIMMYT), MEXICO, and Sides 12 (No.35) and Egypt 1 (No.36) from Egypt. The experimental design was a randomized complete block design with three replicates and the treatments were arrangement in a split-plot. The sowing dates and genotypes were randomly assigned to the main plot and sub-plot, respectively. Each genotype was sown in a plot of $10.5 \mathrm{~m}^{2}$ area. Wheat genotypes were sown in the field at two dates, 15 November (favorable) and 28 December (heat stress), during winter season of 2012/2013 and 2013/2014. 
J. Plant Production, Mansoura Univ., Vol. 6 (3), March, 2015 
The first location was carried out at the Experimental Farm, Faculty of Agriculture, Sohag University, Sohag, Egypt, which located about 600 kilometres from the second location of the Experimental Farm, Field Crops Research Institute, ARC, Aswan, Egypt. The mean daily maximum and minimum temperatures from the time of sowing date to harvest at the two locations are given in Table 2.

Table 2: Means of the maximum and minimum air temperatures $\left({ }^{\circ} C^{\star}\right)$, during wheat growth stages in favorable and late sowing at Sohag and Aswan locations.

\begin{tabular}{|c|c|c|c|c|c|}
\hline \multirow{3}{*}{ Locations } & \multirow{3}{*}{ Months } & \multicolumn{4}{|c|}{ Years } \\
\hline & & \multicolumn{2}{|c|}{$2012 / 2013$} & \multicolumn{2}{|c|}{$2013 / 2014$} \\
\hline & & Max. & Min. & Max. & Min. \\
\hline Sohag & \multirow[t]{2}{*}{ November } & 22.03 & 8.57 & 29.23 & 13.52 \\
\hline Aswan & & 27.00 & 8.40 & 30.00 & 11.4 \\
\hline Sohag & \multirow[t]{2}{*}{ December } & 21.37 & 7.55 & 24.41 & 10.18 \\
\hline Aswan & & 24.70 & 6.1 & 24.80 & 7.9 \\
\hline Sohag & \multirow[t]{2}{*}{ January } & 18.93 & 4.22 & 19.05 & 7.51 \\
\hline Aswan & & 21.50 & 3.00 & 25.50 & 6.3 \\
\hline Sohag & \multirow[t]{2}{*}{ February } & 20.81 & 7.09 & 27.64 & 9.42 \\
\hline Aswan & & 26.80 & 9.00 & 28.00 & 8.3 \\
\hline Sohag & \multirow[t]{2}{*}{ Mars } & 23.20 & 8.00 & 28.02 & 10.83 \\
\hline Aswan & & 28.80 & 9.90 & 32.20 & 12.8 \\
\hline Sohag & \multirow[t]{2}{*}{ April } & 33.49 & 20.53 & 31.58 & 15.75 \\
\hline Aswan & & 36.6 & 16.40 & 33.90 & 14.6 \\
\hline Sohag & \multirow[t]{2}{*}{ May } & 36.00 & 25.60 & 39.55 & 26.41 \\
\hline Aswan & & 35.20 & 17.6 & 39.80 & 20.40 \\
\hline
\end{tabular}

*Egyptian Meteorological Authority.

Traits measured:

Data of flag leaf area (leaf length $x$ width $x$ 0.75) was measured according to Jatimliansky and Babinec (1984). Days to heading recorded by the number of days elapsed from sowing until the upper most spikes appeared beyond the auricles of the flag leaf sheath (50\% heading). Spike length was recorded in $(\mathrm{cm})$ for mean of ten main spikes/plot. The number of kernels/spike and weight of 1000-kernel were recorded. Grain yield (ton/ht.) from each replication $10.5 \mathrm{~m}^{2}$ area was harvested to calculate grain yield.

Statistical analysis:

The combined analysis of variance was performed according to Gomez and Gomez (1984). The stability analysis was, however, computed as outlined by Eberhart and Russell (1966). Data analysis for genotypes, revised least significant difference (LSD') between genotypes and the interaction among genotypes and other factors were calculated. The analyses of variance were computed using MSTATC microcomputer program (MSTATC 1990). The stability parameters for all studied traits using SPSS (version 10) program were used to develop graphical illustration (SPPS 1995).

\section{RESULTS AND DISCUSSIONS}

\section{Environments effect:}

Results indicated that, the wide range of weather conditions resulted in a broad variation of mean yields, ranging from $6.59 \mathrm{t} / \mathrm{ha}$ in favorable sowing date to $4.99 \mathrm{t} / \mathrm{ha}$ in late sowing date as heat stress (Table 3). Sowing 
dates of the trial varied within each environment and may have had an impact on grain yield. The locations with a later sowing date were exposed to higher temperature stress early in the crop season, which may have affected crop growth and final grain yield. Sohag and Aswan locations differed by 0.30 in mean grain yield. Mondal et al. (2013) found, every $1^{\circ} \mathrm{C}$ rise in temperature there was a $7-8 \%$ loss in grain yield. Based on the study results, we are in agreement with Aggarwal et al. (2010) and Lobell et al. (2008), they reported yield losses of $6-20 \%$ for South Asia and the Eastern Gangetic wheat growing regions by various simulation studies.

Table 3: Means of traits for the thirty six genotypes over years, sowing dates and locations.

\begin{tabular}{|l|c|c|c|c|c|c|}
\hline Item & $\begin{array}{c}\text { Days to } \\
\text { heading }\end{array}$ & $\begin{array}{c}\text { Flag leaf } \\
\text { area }\end{array}$ & $\begin{array}{c}\text { Spike } \\
\text { length }\end{array}$ & $\begin{array}{c}\text { Number of } \\
\text { kernels/spike }\end{array}$ & $\begin{array}{c}\text { 1000-kernel } \\
\text { weight }\end{array}$ & $\begin{array}{c}\text { Grain } \\
\text { yield }\end{array}$ \\
\hline First year & 87.43 & 23.01 & 11.54 & 47.51 & 45.95 & 5.88 \\
\hline Second year & 85.28 & 22.64 & 11.14 & 46.53 & 44.54 & 5.70 \\
\hline \multicolumn{7}{|l|}{} \\
\hline $\begin{array}{l}\text { Favorable } \\
\text { sowing date }\end{array}$ & 94.05 & 24.40 & 12.17 & 51.70 & 52.10 & 6.59 \\
\hline $\begin{array}{l}\text { Late sowing } \\
\text { date }\end{array}$ & 78.66 & 21.25 & 10.51 & 42.33 & 38.40 & 4.99 \\
\hline \begin{tabular}{l}
$\mid 7$ \\
\hline Sohag location
\end{tabular} & 87.29 & 23.44 & 11.64 & 48.55 & 48.99 & 5.89 \\
\hline Aswan location & 85.42 & 22.21 & 11.04 & 45.49 & 41.50 & 5.69 \\
\hline \multicolumn{7}{|l|}{} \\
\hline Mean overall & 86.36 & 22.83 & 11.34 & 47.02 & 45.25 & 5.79 \\
\hline
\end{tabular}

Late sowing date during crop growth and development at Sohag location, resulted in a $5.89 \mathrm{t} / \mathrm{ha}$ higher mean grain yield than at Aswan location which produced 5.69 t/ha (Table 3). In the two locations, temperatures were relatively warmer during crop growth and grain filling stage, which not only had an impact on grain yield but also on days to heading traits. A reduction in flag leaf area, days to heading, spike length, number of kernels/spike, 1000-kernel weight and grain yield were observed under the high temperatures of Aswan location (Table 2). Continuous warm temperatures decreased the mean of days to heading at Sohag and Aswan locations by 15.61 and 15.18 days, respectively compared to favorable sowing date (Table 5). Previous studies have reported similar effects of high temperature stress on days to heading (Yang et al. 2002, Mason et al. 2010 and Mondal et al. 2013). Mondal et al. (2013) reported that the locations with a later sowing date were exposed to higher temperature stress early in the crop season, which may have affected crop growth and final grain yield.

The grain yield differed through years which ranged from $5.88 \mathrm{t} / \mathrm{ha}$ in $2012 / 2013$ to $5.70 \mathrm{t} / \mathrm{ha}$ in $2013 / 2014$ (Table 3 ). This due to the high temperatures input during grain filling period in 2013/2014, whereas wheat production is often limited by terminal heat stress. The results in Table 2 showed wide fluctuations of the temperature over the growing seasons. 
Temperatures at different growing stages of the same sowing date were not fixed in the two seasons of the study. Moreover, the temperature of growing months fluctuated from season to another season and from location to another location. The results showed that grain yield was decreased about $24.28 \%$ under late sowing date (Table 3). Rosenzweig and Tubiello (1996) reported that consistent decreases in wheat yield due to daily temperature rise. Li et al. (2014) demonstrated that yield potential varied greatly across locations.

Interactions effect:

The combined analysis of variance revealed that the interactions between genotypes $(G)$, sowing dates $(D)$, years $(Y)$ and locations $(L)$ for all studied traits were highly significant (Table 4). The differences between the $Y^{*} L, Y^{*} D, L^{*} D, Y^{*} L^{*} D, Y^{*} G, L^{*} G, Y^{*} L^{*} G, D^{*} G$ and $Y^{*} D^{*} G$ were highly significant were observed for all studied traits. Highly significant differences between the $L^{*} D^{*} G$ for all studied traits, except days to heading and flag leaf area, while differences between the $Y^{*} L^{*} D^{*} G$ were significant for all studied traits except days to heading and spike length. These results indicated that the studied genotypes responded differently to the different environmental conditions suggesting the importance of the assessment of genotypes under different environments in order to identify the best genetic make up for a particular environment. El-Morshidy et al. (2001) and Tawfelis (2006) found significant variation in yield and yield components among wheat genotypes under favorable and late planting. Hamam and Khaled (2009) and El Ameen (2012) showed highly significant differences between genotypes as well as (genotypes $x$ environment) for flag leaf area, days to heading, spike length, number of kernels/spike, 1000-kernel weight and grain yield.

Table 4: The combined analyses of variance over years $(Y)$, locations (L), sowing dates (D) and genotypes (G) for studied all traits.

\begin{tabular}{|c|c|c|c|c|c|c|c|c|}
\hline $\begin{array}{l}\text { Source of } \\
\text { variation }\end{array}$ & d.f & $\begin{array}{c}\text { Flag leaf } \\
\text { area }\end{array}$ & $\begin{array}{l}\text { Days to } \\
\text { heading }\end{array}$ & $\begin{array}{c}\text { Flag leaf } \\
\text { area }\end{array}$ & $\begin{array}{l}\text { Spike } \\
\text { length }\end{array}$ & $\begin{array}{c}\text { Number of } \\
\text { kernels/spike }\end{array}$ & $\begin{array}{c}\text { 1000- } \\
\text { kernel } \\
\text { weight }\end{array}$ & $\begin{array}{l}\text { Grain } \\
\text { yield }\end{array}$ \\
\hline Year (Y) & 1 & $326.98^{* *}$ & $50.57^{* *}$ & $326.98^{* *}$ & $8.86^{* *}$ & $221.4^{* *}$ & $121.691^{* *}$ & $8.51^{* *}$ \\
\hline Location (L) & 1 & $28.96^{\star *}$ & $998.18^{\star \star}$ & $28.96^{\star \star}$ & $33.47^{\star \star}$ & $206.6^{\star \star}$ & $427.84^{\star \star}$ & $7.64^{\star \star}$ \\
\hline$Y^{*} \mathrm{~L}$ & 1 & $134.41^{\star \star}$ & $998.18^{\star \star}$ & $134.41^{\star \star}$ & $6.95^{\star \star}$ & $431.42^{\star \star}$ & $218.76^{\star \star}$ & $7.64^{\star \star}$ \\
\hline Error (a) & 8 & 3.39 & 24.03 & 3.39 & 3.43 & 7.32 & 7.24 & 4.54 \\
\hline $\begin{array}{l}\text { Sowing dates } \\
\text { (D) }\end{array}$ & 1 & $213.81^{\star \star}$ & $512.85^{\star \star}$ & $213.81^{* *}$ & $589.55^{\star *}$ & $189.59^{\star *}$ & $205.56^{\star *}$ & $353.18^{* *}$ \\
\hline$Y^{*} D$ & 1 & 118. & $54.34^{\star \star}$ & 118. & 18.6 & $1661.48^{\star \star}$ & $1179.43^{\star \star}$ & $19.93^{\star \star}$ \\
\hline$L^{\star}{ }^{2}$ & 1 & $0.29^{\star *}$ & $9.76^{\star \star}$ & $0.29^{\star \star}$ & $0.20^{\star *}$ & $3.85^{\star \star}$ & $10.93^{\star *}$ & $0.14^{\star \star}$ \\
\hline$Y^{*} L^{*} D$ & 1 & $0.76^{\star *}$ & $9.76^{\star *}$ & $0.76^{* *}$ & $0.07^{\star \star}$ & $9^{\star *}$ & $6.25^{\star \star}$ & $0.14^{\star \star}$ \\
\hline $\begin{array}{l}\text { Genotypes } \\
\text { (G) }\end{array}$ & 35 & $335.7^{* *}$ & $121.34^{\star \star}$ & $335.7^{* *}$ & $44.01^{* *}$ & $1598.37^{* *}$ & $1090.15^{\star *}$ & $57.9^{* *}$ \\
\hline$Y^{*} G$ & 35 & $1.11^{* *}$ & $54.66^{\star \star}$ & $1.11^{* *}$ & $0.14^{* *}$ & $15.06^{* *}$ & $15.43^{* *}$ & $4.9^{* *}$ \\
\hline$L^{*} \mathrm{G}$ & 35 & $0.02^{\star \star}$ & $0.049^{\star \star}$ & $0.02^{* \star}$ & $0.013^{\star *}$ & $0.15^{\star \star}$ & $0.24^{\star \star}$ & $0.124^{\star \star}$ \\
\hline$Y^{*} L^{*} G$ & 35 & $0.10^{* *}$ & $0.049^{* *}$ & $0.10^{* *}$ & $0.002^{* *}$ & $0.34^{* *}$ & $0.11^{* *}$ & $0.124^{\star *}$ \\
\hline$D^{*} \mathrm{G}$ & 35 & $6.16^{\star *}$ & $5.04^{\star *}$ & $6.16^{* *}$ & $0.034^{* *}$ & $37.84^{* *}$ & $40.99^{* *}$ & $2.59^{* *}$ \\
\hline$Y^{*} D^{*} G$ & 35 & $0.86^{* *}$ & $0.26^{\star *}$ & $0.86^{* *}$ & $0.13^{\star *}$ & $34.57^{* *}$ & $7.74^{\star *}$ & $1.02^{* \star}$ \\
\hline$L^{*} D^{*} G$ & 35 & 0.001 & 0.0001 & 0.001 & 0.001 & $0.02^{\star \star}$ & $0.014^{* \star}$ & $0.004^{\star \star}$ \\
\hline$Y^{*} L^{*} D^{*} G$ & 35 & $0.002^{*}$ & 0.0001 & $0.002^{*}$ & 0.001 & $0.021^{\star \star}$ & $0.01^{\star *}$ & $0.004^{\star \star}$ \\
\hline Error (b) & 568 & 0.002 & 0.004 & 0.002 & 0.0001 & 0.005 & 0.005 & 0.0002 \\
\hline
\end{tabular}

*,** Significant at 0.05 and 0.01 probability levels, respectively. 


\section{Performance of genotypes:}

Sowing at the favorable date (November) increased all studied traits (Table 3). Flag leaf area, days to heading, spike length, number of kernels/spike, 1000-kernel weight and grain yield traits were increased under Sohag location. The results revealed that wheat genotypes responded differently when they were grown at different seasons.

The flag leaf area:

The average of flag leaf area ranged from 14.07 to $29.41 \mathrm{~cm}$ for genotypes No. 2 and 6, respectively with an overall average of $22.83 \mathrm{~cm}$. Flag leaf area decreased (12.89\%) by delaying in sowing date (Table 5). When growth resources are limited by heat stress, the size of plant organs such as leaves, tillers, and spikes is reduced (Fischer 1984). Hamam and Khaled (2009) found, flag leaf area decreased (13.29\%) by delaying in sowing date.

Days to heading:

The average of number of days to heading in late sowing date was reduced by 15.4 days. The mean number of days to heading of the different genotypes ranged from 80.08 (Genotype No. 25) to 93.23 (Genotype No. 33) days, with an overall average 86.36 days. The earliest genotypes were No. 25 (72.74 days) and No. 24 (74.78 days) at Aswan location in the second sowing date (Table5). Sivori (1975) reported a delay of 3 days in flowering of wheat by a delay of 15 days in sowing date. In addition, Nachit and Ketata (1987) stated that the number of days to heading tended to decrease by delaying sowing date. High temperatures after heading were detrimental to grain filling (Royo et al. 2006), especially for late-heading subpopulations. Spring varieties were the most stable regarding grain weight, probably because their earliness limited the damage to their grain formation caused by terminal stresses. 
Table 5: Genotype means (G) at two locations (L) and two sowing dates (D) for flag leaf area and days to heading combined over two years.

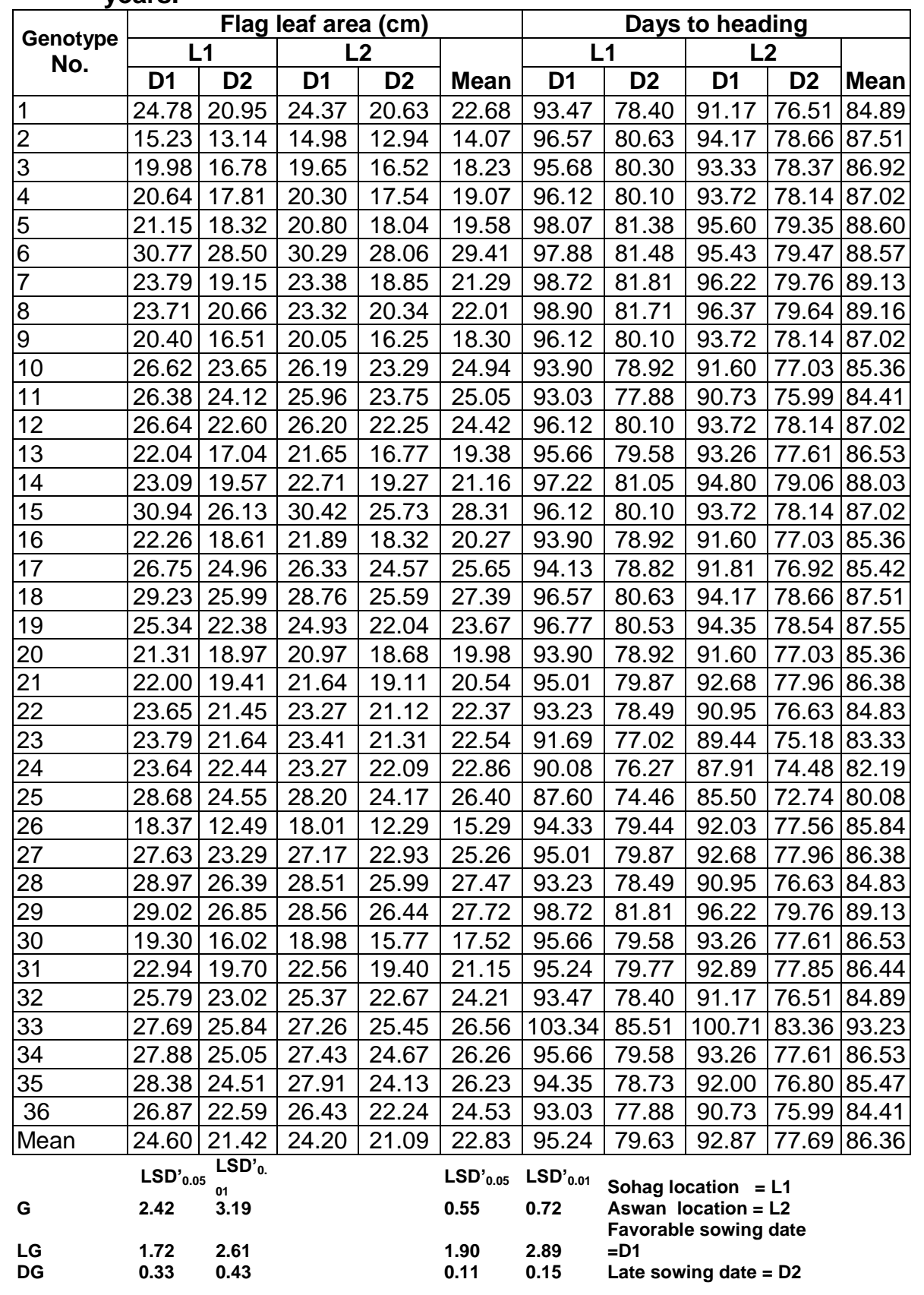




\section{Spike length:}

The shortest spike length was $7.63 \mathrm{~cm}$ for genotype No. 19 under late sowing date at Aswan location, while the tallest spike length was $16.49 \mathrm{~cm}$ for genotype No. 18 at Sohag location under favorable sowing date with an overall average $11.34 \mathrm{~cm}$ (Table 6). Sowing at the favorable date at Sohag location caused taller spikes, because heat units and metabolites stored in favorable sowing date caused taller plants, vigorous growth and taller spikes. Hamam and Khaled (2009) reported sowing at the favorable date under Assiut location caused taller spikes, because heat units and metabolites stored in favorable sowing date caused taller plants, vigorous growth and taller spikes. In this regard, El Ameen (2012) found decreasing in spike length under late sowing date.

\section{The number of kernels/spike:}

The average of number of kernels/spike ranged from 31.11 (No. 9) to 66.96 (No. 18), with an overall average of 47.02 kernels. The trait decreased approximately $18.13 \%$ by delaying in sowing date (Table 6 ). Abdel-Majeed (2005) and El Ameen (2012) found some genotypes had high mean of number of kernel/spike under favorable conditions.

1000-Kernel weight:

The highest weight of kernel was found for genotype No. 19 (65.99 g) at Sohag location under the favorable sowing date, but the lowest value was for genotype No. $13(22.88 \mathrm{~g})$ under Aswan location in late sowing date with an overall average $45.25 \mathrm{~g}$ (Table 7). This may be due to high temperatures affecting the grain maturity which resulted in shrunk kernels. These results, were the same trend with obtained by Menshawy (2007) who reported high reduction in kernel weight were found under late planting; it could be fully accounted by the reduction in grain filling period. Tawfelis (2006) and El Ameen (2012) documented that delaying in sowing reduced 1000-kernel weight and grain yield. Previous studies have reported similar reduction in 1000-kernel weight in response to high temperature stress (Wardlaw et al. 2002, Hays et al. 2007 and Mondal et al. 2013). Although 1000-kernel weight was reduced in late sowing date, it is important to note that most entries with high 1000-kernel weight under high temperature stress also maintained higher 1000-kernel weight in Sohag than Aswan locations. Due to its association with grain yield, 1000-kernel weight was suggested as a selection criterion under high temperature stress (Reynolds et al. 1994, Yang et al. 2002 and Sharma et al. 2008).

\section{Grain yield:}

Grain yield of the genotypes ranged from 3.64 to 8.25 ton/ht. for genotypes No. 30 and No. 22, respectively, with an overall average of 5.79 ton/ht. The genotype No. 2 grown at Sohag produced the highest grain yield (9.27 ton/ht.) during the favorable condition of wheat sown (Table 7). The grain yield was greatly affected by the main yield components like number of kernels/spike and 1000-kernel weight. 
Hamam, K. A. et al.

6

358 
J. Plant Production, Mansoura Univ., Vol. 6 (3), March, 2015

7 
The delay in heading date under late sowing was attributed to grains could be affected by high temperature special during this period. Reducing in flag leaf area, spike length, number of kernels/spike and 1000-kernel weight caused a great reduction in grain yield. El Ameen (2012) reported that delaying the sowing date resulted in a substantial reduction in grain yield by $63.34 \%$, while the genotypes under favorable conditions perform well for grain yield. Blum (1988) documented that drought stress during the grain filling period reduced grain yield. Reduction in grain yield reached $23 \%$ from as little as 4 days exposure to very high temperature (Randall and Moss 1990). Schulthess et al. (2013) reported, the genotype $\times$ environment interaction has more importance for the grain yield.

\section{Stability analysis:}

The joint regression analysis of variance (Table 8) revealed highly significant differences among genotypes for all studied traits. The partitioning of the genotype $\times$ environment interaction, as indicated by Env.+ ( $G \times$ Env.), Env.(Linear), were highly significant for all studied traits. $G \times E$ (linear) was highly significant for all studied traits. Because $G \times E$ (linear) was significant, it could be proceeded in the stability analysis (Eberhart and Russell 1966).

Table 8: Joint regression analyses of variance studied traits of bread wheat over six environments (two sowing date, two years and two locations).

\begin{tabular}{|c|c|c|c|c|c|c|c|}
\hline \multirow[b]{2}{*}{$\begin{array}{l}\text { Source of } \\
\text { variation }\end{array}$} & \multirow[b]{2}{*}{ D.f } & \multicolumn{6}{|c|}{ Means of squares } \\
\hline & & \begin{tabular}{|c|}
$\begin{array}{c}\text { Flag leaf } \\
\text { area }\end{array}$ \\
\end{tabular} & $\begin{array}{l}\text { Days to } \\
\text { heading }\end{array}$ & $\begin{array}{l}\text { Spike } \\
\text { length }\end{array}$ & \begin{tabular}{|c|} 
Number of \\
kernels/spike
\end{tabular} & $\begin{array}{c}\text { 1000-kernel } \\
\text { weight }\end{array}$ & Grain yield \\
\hline Genotypes (G) & 35 & $335.69^{\star \star}$ & $121.32^{\star *}$ & $44.01^{* *}$ & $1598.33^{\star *}$ & $1090.16^{\star \star}$ & $57.91^{\star \star}$ \\
\hline $\begin{array}{l}\text { Env.+ (G x } \\
\text { Env.) }\end{array}$ & 252 & $392.22^{* *}$ & $7804.87^{\star \star}$ & $103.84^{\star *}$ & $3334.43^{* *}$ & $7777.28^{* *}$ & $86.39^{* *}$ \\
\hline Env. (linear) & 1 & $796.13^{\star \star}$ & $7600.37^{\star *}$ & $242.99^{\star \star}$ & $5725.72^{\star \star}$ & $2224.03^{\star \star}$ & $78.86^{\star \star}$ \\
\hline $\begin{array}{l}\text { G x Env. } \\
\text { (linear) }\end{array}$ & 35 & $182.77^{\star \star}$ & $2580.68^{* *}$ & $79.33^{\star *}$ & $1951.17^{* *}$ & $6871.21^{* *}$ & $20.83^{*}$ \\
\hline $\begin{array}{l}\text { Pooled } \\
\text { deviation }\end{array}$ & 216 & $0.14^{* *}$ & $40.53^{\star \star}$ & $0.35^{\star *}$ & $5.11^{* *}$ & $45.34^{\star *}$ & $0.92^{* *}$ \\
\hline Pooled error & 560 & 0.001 & 0.0002 & 0.005 & 0.0002 & 0.006 & 0.004 \\
\hline
\end{tabular}

*,** Significant at 0.05 and 0.01 probability levels, respectively.

Highly significant $G \times E$ interactions for many wheat traits were previously reported (Mahak et al. 2002; Mondal and Khajuria 2002; Kheiralla et al. 2004, Mahmoud 2006; Hamam and Khaled 2009 and El Ameen 2012). Flag leaf area $(\mathrm{cm})$ : The stability parameters $\left(b_{i}\right.$ and $\left.s_{d}{ }_{d}\right)$ and the mean performance $(\bar{x})$ of the genotypes are presented in Table 9 and illustrated graphically in Fig.1. The genotypes No. 3, 8, 10, 14, L18, 19, 30, 31 and 34 were stable for flag leaf area which $b_{i}$ was little more or less than one and $\mathrm{S}^{2} \mathrm{~d}_{\mathrm{i}}$ equal to zero, therefore these genotypes were stable. Concerning of days to heading, the results indicated that out of thirty six, thirty four genotypes were unstable and gave significant $S^{2} d_{i}$ (Table 9 and Fig.1). 
J. Plant Production, Mansoura Univ., Vol. 6 (3), March, 2015 


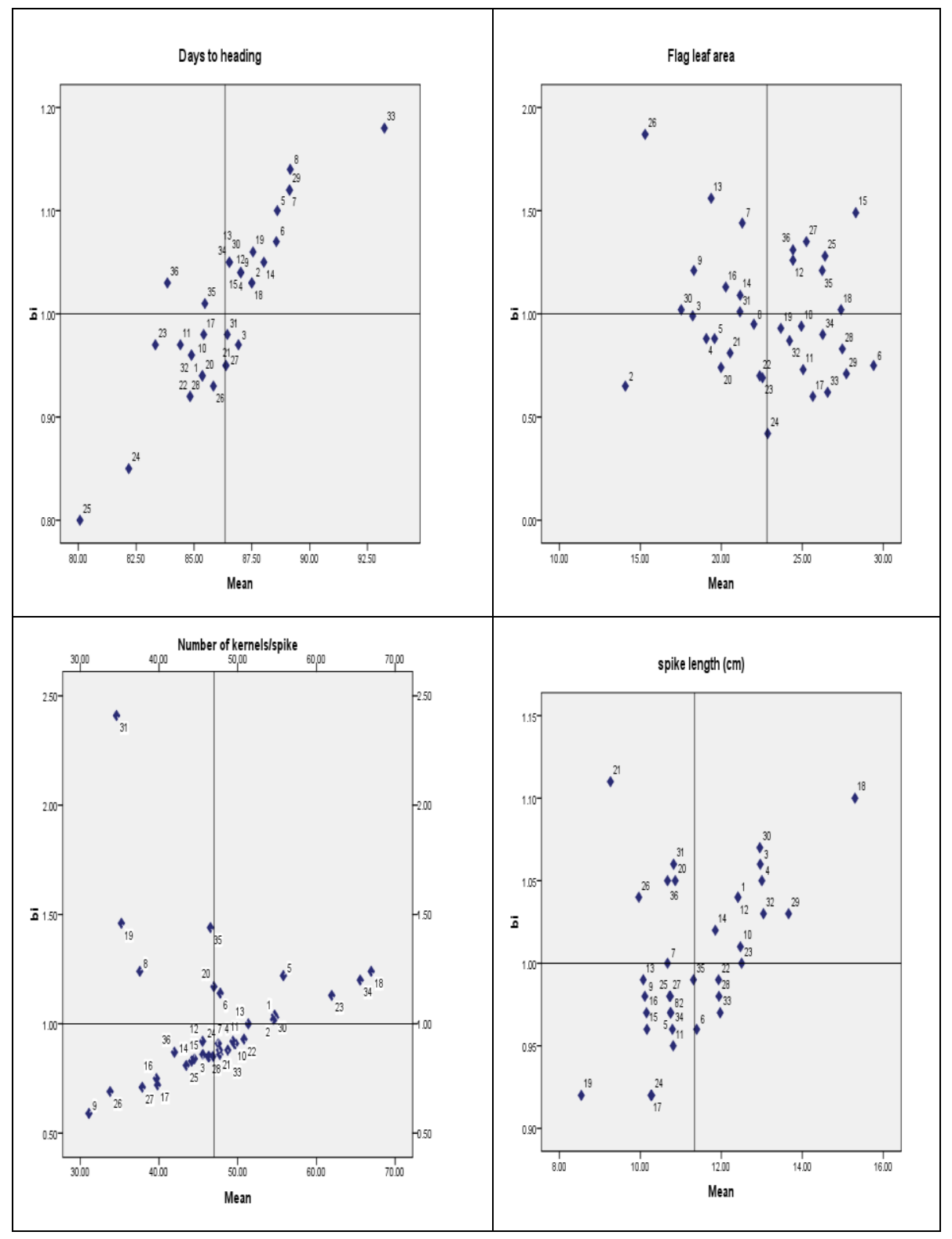

Fig. 1: Graphical illustration of the stability parameter $\left(b_{i}\right)$ and mean performance genotypes $(\bar{x})$ for flag leaf area, days to heading, spike length and number of kernels/spike. 
Genotypes No. 2 and 18 were stable and adapted to stress environments, whereas $b_{i}$ and $S^{2} d_{i}$ were not significant from unity and zero, respectively. The results of Spike length $(\mathrm{cm})$ in Table 9 and Fig. 1 showed, genotypes No. 7, 10 and 23 were stable for spike length, whereas $S^{2} d_{i}$ and $b$ were not significant from unity and $b_{i}$ was equal to one and $S^{2} d_{i}$ equal to zero. As for number of kernels/spike, the genotypes No. 3, 4, 5, 12, 14, 15, 16, 20 and 25 were stable for number of kernels/spike (Table 10 and Fig. 1). In the meantime, the genotypes No. 4, 5, 12, 20 and 25 were also stable for 1000kernel weight (Table 10 and Fig.2). 1000-kernel weight (g) genotypes No. 1, $2,3,4,5,8,12,14,16,20,21$ and 25 were stable for 1000-kernel weight, whereas the $b_{i}$ for most genotypes was equal or more or less than one and $S^{2} d_{i}$ tend to zero. There are also genotypes No. 5 and 14 which are stable for grain yield (Table 10 and Fig.2). Regarding to grain yield, results in Table 10 showed that genotypes No. 5, 6, 14, 20, 22, 24 and 32 were stable for grain yield. The $b_{i}$ values for genotypes No. 6, 22 and 32 were less than one and this result indicated that, these genotypes were stable for stress environments. Finlay and Wilkinson (1963) further stated that the overall yield should be taken into account in addition to the regression of a genotype. Genotypes with a high mean yield and regression near 1.0 are then well adapted to all environments and as the mean yield decreases, a higher or lower regression indicates adaptation to favorable or unfavorable environments, respectively. Eberhart and Russell (1966) added that a stable variety would be one with a regression line slope near 1.0 with a small sum of squared deviations. Breese (1968) illustrated that the joint regression model was a powerful tool in the analysis of $\mathrm{G} \times \mathrm{E}$ interactions. Annicchiarico et al. (2006) also showed that joint regression model proved valuable for definition of recommendations on the basis of mean values of wheat. Thus, the linear regressions of individual genotypic values on the mean value of all genotypes for each environment provide measures of response which can be used to predict relative performance over a range of environmental conditions. Genotypes tend to have their own characteristic values for regression coefficient and deviation from regression mean square as shown in wheat by Joppa et al. (1971) and Busch et al. (1976). Genotypes with high yield and high stability can be found simultaneously using regression parameters as shown by Jalaluddin and Harrison (1993) in wheat.

The correlation between $b_{i}$ and $\bar{x}$ for flag leaf area was negative (0.17 ), respectively. Positive correlation was found for days to heading, spike length, number of kernels/spike, 1000 -kernel weight and grain yield $\left(0.89^{* *}\right.$, $0.50^{* *}, 0.07,0.13$ and $0.51^{\star \star}$ ), respectively (Table 9 and 10 ). The positive and significant correlation for grain yield revealed that the studied genotypes exhibited high performance and high sensitivity to environments. 
Table 10: Genotypes average performance over 6 environments and stability parameters of the thirty six wheat genotypes for number of kernels/spike, 1000-kernel weight and grain yield.

\begin{tabular}{|c|c|c|c|c|c|c|c|c|c|}
\hline \multirow{2}{*}{$\begin{array}{l}\text { Genotype } \\
\text { No. }\end{array}$} & \multicolumn{3}{|c|}{$\begin{array}{c}\text { Number of } \\
\text { kernels/spike }\end{array}$} & \multicolumn{3}{|c|}{1000 - kernel weight } & \multicolumn{3}{|c|}{ Grain yield } \\
\hline & $\bar{x}$ & bi & $\mathrm{S}^{2} \mathrm{~d}_{\mathrm{i}}$ & $\bar{x}$ & bi & $S^{2} d_{i}$ & $\bar{x}$ & $b_{i}$ & $S^{2} d_{i}$ \\
\hline 1 & 54.80 & 1.03 & $0.01^{* *}$ & 38.46 & $0.92^{*}$ & 0.00 & 4.12 & 0.61 & $0.24^{\star \star}$ \\
\hline 2 & 54.55 & 1.02 & $0.01^{* *}$ & 43.46 & $0.97^{*}$ & 0.00 & 7.89 & $1.60^{*}$ & $0.07^{\star \star}$ \\
\hline 3 & 45.57 & $0.86^{*}$ & 0.01 & 44.22 & 0.99 & 0.00 & 7.25 & 1.21 & $0.15^{\star \star}$ \\
\hline 4 & 49.40 & $0.92^{*}$ & 0.01 & 42.84 & $0.97^{*}$ & 0.00 & 5.75 & $1.35^{\star}$ & $0.01^{\star \star}$ \\
\hline 5 & 55.80 & $1.22^{*}$ & 0.00 & 45.28 & 0.99 & 0.00 & 5.30 & \begin{tabular}{|l|}
1.09 \\
\end{tabular} & 0.00 \\
\hline 6 & \begin{tabular}{|l|}
47.78 \\
\end{tabular} & $1.14^{*}$ & $0.04^{\star *}$ & 56.07 & $1.10^{*}$ & $0.72^{\star \star}$ & 6.71 & $0.71^{*}$ & 0.00 \\
\hline 7 & 47.53 & $0.91^{*}$ & $0.04^{* *}$ & 42.56 & 0.99 & $0.10^{\star *}$ & 4.82 & \begin{tabular}{|l|}
0.69 \\
\end{tabular} & $0.02^{\star \star}$ \\
\hline 8 & 37.56 & $1.24^{*}$ & $0.09^{* \star}$ & 52.99 & $1.10^{*}$ & 0.00 & 4.02 & $0.36^{*}$ & $0.03^{\star \star}$ \\
\hline 9 & 31.10 & $0.59^{*}$ & 0.00 & 49.38 & $1.09^{*}$ & $0.08^{\star \star}$ & 4.14 & $0.35^{\star}$ & $0.14^{\star \star}$ \\
\hline 10 & 49.56 & $0.91^{*}$ & $0.03^{* *}$ & 38.01 & $1.38^{*}$ & $4.41^{\star *}$ & 3.88 & $0.45^{*}$ & $0.03^{\star \star}$ \\
\hline 11 & \begin{tabular}{|l|}
49.73 \\
\end{tabular} & $0.91^{*}$ & $0.09^{\star *}$ & 44.96 & 0.96 & $0.11^{\star *}$ & 5.56 & \begin{tabular}{|l|}
1.30 \\
\end{tabular} & $0.07^{\star \star}$ \\
\hline 12 & 45.54 & $0.92^{*}$ & 0.00 & 41.28 & $0.95^{*}$ & 0.00 & 3.85 & 0.98 & $0.22^{\star \star}$ \\
\hline 13 & 51.34 & 1.00 & $0.23^{* *}$ & 31.46 & $1.29^{*}$ & $14.75^{\star \star}$ & 6.48 & 1.18 & $0.27^{\star \star}$ \\
\hline 14 & \begin{tabular}{|l|}
44.14 \\
\end{tabular} & $0.83^{*}$ & 0.00 & 51.95 & $1.10^{*}$ & 0.00 & 7.89 & $1.14^{*}$ & 0.00 \\
\hline 15 & 44.49 & $0.84^{*}$ & 0.00 & 42.06 & $1.22^{*}$ & $0.24^{\star \star}$ & 3.85 & $0.56^{*}$ & $0.03^{\star \star}$ \\
\hline 16 & 39.67 & $0.75^{\star}$ & 0.00 & 49.80 & $1.08^{*}$ & 0.00 & 3.68 & 0.78 & $0.02^{\star \star}$ \\
\hline 17 & 39.81 & $0.72^{*}$ & $0.08^{* *}$ & 43.68 & $1.16^{*}$ & $0.53^{\star *}$ & 3.68 & 0.76 & $0.02^{\star \star}$ \\
\hline 18 & 66.95 & $1.24^{*}$ & $0.10^{* *}$ & 39.04 & 0.16 & $5.48^{* *}$ & 7.00 & $1.76^{*}$ & $0.09^{\star \star}$ \\
\hline 19 & 35.22 & 1.46 & $72.42^{* *}$ & 56.99 & $1.15^{*}$ & $0.03^{* *}$ & 7.90 & $0.79^{*}$ & 0.00 \\
\hline 20 & 46.97 & $1.17^{*}$ & 0.00 & 33.87 & $0.93^{*}$ & 0.00 & 5.87 & 1.09 & 0.02 \\
\hline 21 & 47.68 & $0.88^{*}$ & $0.02^{* \star}$ & 36.56 & $0.94^{*}$ & 0.00 & 7.41 & 1.36 & 1.17 \\
\hline 22 & 50.80 & 0.93 & $0.07^{\star *}$ & 53.95 & $1.09^{*}$ & $0.18^{\star \star}$ & 8.25 & $0.68^{*}$ & 0.00 \\
\hline 23 & 61.94 & $1.13^{*}$ & $0.18^{* \star}$ & 48.44 & 1.01 & $0.12^{\star \star}$ & 7.83 & \begin{tabular}{|l|}
1.44 \\
\end{tabular} & $0.08^{\star \star}$ \\
\hline 24 & \begin{tabular}{|l|}
47.72 \\
\end{tabular} & $0.86^{*}$ & $0.30^{* *}$ & 35.33 & $0.82^{*}$ & $0.21^{\star *}$ & 5.95 & $1.39^{*}$ & 0.00 \\
\hline 25 & 43.46 & $0.81^{*}$ & 0.00 & 43.99 & $0.99^{*}$ & 0.00 & 5.63 & \begin{tabular}{|l|}
0.89 \\
\end{tabular} & $0.05^{\star \star}$ \\
\hline 26 & 33.79 & $0.69^{*}$ & $0.76^{\star *}$ & 40.30 & 1.04 & $10.56^{\star \star}$ & 4.04 & 0.73 & $0.20^{\star \star}$ \\
\hline 27 & \begin{tabular}{|l|}
37.87 \\
\end{tabular} & $0.71^{*}$ & 0.00 & 52.01 & $0.92^{*}$ & $0.06^{\star *}$ & 3.75 & 0.93 & $0.19^{\star \star}$ \\
\hline 28 & 46.37 & $0.85^{\star}$ & $0.06^{* *}$ & 43.49 & 0.95 & $0.07^{\star *}$ & 5.31 & 1.04 & $0.03^{\star \star}$ \\
\hline 29 & 46.83 & $0.85^{*}$ & $0.12^{\star \star}$ & 36.15 & $0.86^{*}$ & $0.07^{\star *}$ & 7.66 & 1.44 & $0.23^{\star \star}$ \\
\hline 30 & \begin{tabular}{|l|}
54.68 \\
\end{tabular} & 1.04 & $0.02^{\star \star}$ & 48.03 & $0.87^{*}$ & $0.12^{\star \star}$ & 3.64 & 1.13 & $0.13^{\star \star}$ \\
\hline 31 & 34.60 & $2.41^{*}$ & $977.19^{* *}$ & 58.45 & $0.83^{*}$ & $0.36^{\star *}$ & 7.81 & 0.48 & $0.45^{\star \star}$ \\
\hline 32 & 46.26 & $0.85^{\star}$ & $0.03^{* *}$ & 49.01 & $0.93^{*}$ & $0.06^{\star *}$ & 6.53 & 0.99 & 0.00 \\
\hline 33 & \begin{tabular}{|l|}
48.74 \\
\end{tabular} & $0.88^{*}$ & $0.18^{\star \star}$ & 52.61 & 1.05 & $0.74^{\star \star}$ & 5.23 & 0.77 & $0.17^{\star \star}$ \\
\hline 34 & 65.56 & $1.20^{*}$ & $0.14^{\star *}$ & 47.52 & 1.01 & $0.04^{* *}$ & 7.28 & 1.72 & $1.46^{\star \star}$ \\
\hline 35 & 46.53 & $1.44^{*}$ & $0.10^{\star *}$ & 45.38 & $1.14^{*}$ & 0.01 & 5.89 & 1.05 & $0.17^{\star \star}$ \\
\hline 36 & \begin{tabular}{|l|}
41.96 \\
\end{tabular} & 0.87 & $2.28^{\star \star}$ & 48.88 & 1.09 & $1.61^{\star *}$ & \begin{tabular}{|l|}
6.50 \\
\end{tabular} & 1.11 & $2.82^{\star \star}$ \\
\hline Mean & 47.01 & & & 45.24 & & & 5.79 & & \\
\hline $\mathrm{r}\left(\bar{x}, \mathrm{~b}_{\mathrm{i}}\right)$ & \multicolumn{3}{|c|}{0.07} & \multicolumn{3}{|c|}{0.13} & \multicolumn{3}{|c|}{$0.51^{\text {** }}$} \\
\hline
\end{tabular}




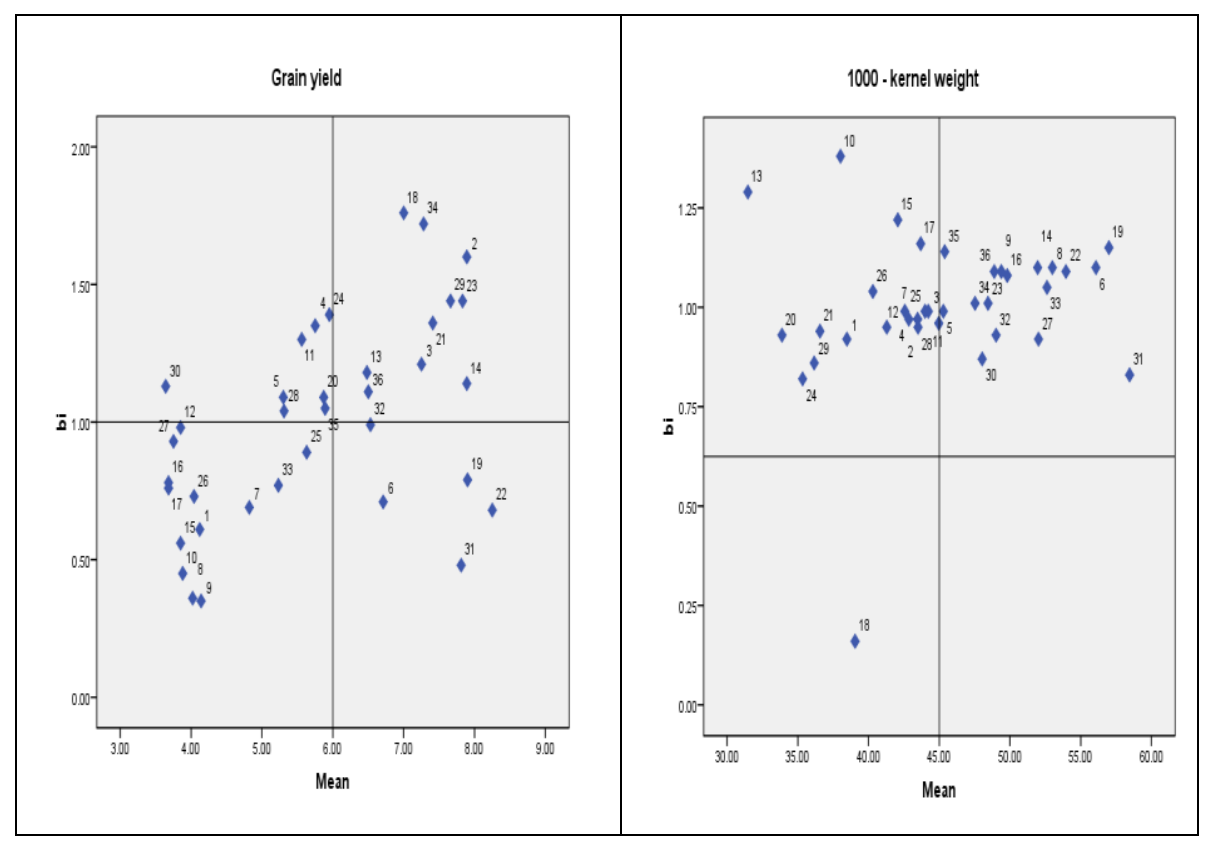

Fig. 2: Graphical illustration of the stability parameter $\left(b_{i}\right)$ and mean performance genotypes $(\bar{x})$ for 1000-kernel weight and grain yield.

\section{CONCLUSION}

In conclusion, the characterizing bread wheat genotypes were mainly classified according to morpho-agronomic traits under heat stress conditions through different days of planting, different locations. The joint regression model is one of the useful methods to characterize the response of genotypes to environments. Breeding for high number of kernels/spike, 1000kernel weight and grain yield, stability can be facilitated by calculating genotypes means and joint regression, in particular when the relationship between genotypic response and the environment is linear. Genotypes No. 2, $3,18,23,29,31$ and 34 were unstable for high yielding, they are not adapted to Egyptian conditions. The genotypes No. 5, 6, 14, 19, 20, 22, 24 and 32 exhibited stability for grain yield and useful in the breeding program in developing new wheat genotypes with tolerance to heat stress conditions. This could be due to adaptation of these genotypes to wide differences in climatic conditions which prevailed at the two studied locations.

Acknowledgements

We thank Prof. Dr. Adel M. Mahmoud, Vice Dean for education and students affairs, Faculty of Agriculture, Assiut University, Egypt, for reading 
this manuscript. We also thank the International Maize and Wheat Improvement Center (CIMMYT) for providing seeds.

\section{REFERENCES}

Abd El-Majeed, A.M; S.A. Mousa and A.A. Abd El-Kareem (2005). Effect of heat stress on some agronomic traits of bread wheat (Triticum aestivum L.) genotypes under Upper Egypt conditions. Fayoum J. Agric. Res. Dev., 19: 4-16.

Aggarwal, P.K; N.S. Kumar and H. Pathak (2010). Impacts of climate change on growth and yield of rice and wheat in Upper Ganga Basin. WWF report, 1-44.

Ali, N; F. Javidfar and Y. Mirza (2003). Selection of stable rapeseed (Brassica napus L.) genotypes through regression analysis. Pak. J. Bot., 35: 175183.

Allard, R.W and A.D. Bradshaw (1964). Implications of genotype environmental interactions in applied plant breeding. Crop Sci., 4: 503507.

Annicchiarico, P; F. Bellah and T. Chiari (2006). Repeatable genotype x location interaction and its exploitation by conventional and GIS-based cultivar recommendation for durum wheat in Algeria. Europ. J. Agronomy, 24: 70-81.

Aslam, M; A. Majid; P.R. Hobbs; N.I. Hashim and D. Byerlee (1989). Wheat in the rice-wheat cropping system of the Punjab: A Synthesis of On-farm Research Results 1984-1989. PARC/CIMMYT paper No. 89-3. CIMMYT, Mexico.

Blum, A. (1988). Plant breeding for stress environments. CRC Press, Florida. Pp. 212.

Blumenthal, C.S; I.L. Batey; F. Bekes; C.W. Wrigley and E.W.R. Barlow (1991). Seasonal changes in wheat-grain quality associated with high temperatures during grain filling. Aust. J. Agric. Res., 42: 21-30.

Breese, E.L. (1968). The measurement and significance of genotypeenvironment interaction in grasses. Heredity, 24: 27-44.

Busch, R.H; J. Hammond and R.C. Frohberg (1976) Stability and performance of hard red spring wheat bulks for grain yield. Crop Sci., 16: 256-259.

Corbellini, M; M.G. Canevara; L. Mazza; M. Ciaffi; D. Lafiandra; L.Tozzi; B.Borghi; (1997). Effect of the duration and intensity of heat shock during grain filling on dry matter and protein accumulation, technological quality and protein composition in bread and durum wheat. Aust. J. Plant Physiol., 24: 245-250.

Crossa, J. (1990). Statistical analysis of multiplication trials. Adv. Agron., 44: 55-85.

Dessouki, S.M; M.M. Sadek; O.S. Khalil and E.H. Tallat (1974). Cultural requirements of new dwarf wheat for maximum production in Egypt. c.f. field Crop Abstr., 31: 3.

Eberhart, S.A and W.A. Russell (1966). Stability parameters for comparing varieties. Crop Sci., 6: 36-40. 
El Ameen, T. (2012). Stability analysis of selected wheat genotypes under different environment conditions in Upper Egypt. Afric. J. Agric. Res., 34: 4838-4844.

El-Morshidy, M.A; K.A. Kheiralla; A.M. Abdel-Ghani and A.A. Abd El-Kareem (2001). Stability analysis for earliness and grain yield in bread wheat. The $2^{\text {nd }}$ plant breed. Conf. October 2, Assiut Univ. Pp. 199-217.

Finlay, K.W and G.N. Wilkinson (1963). The analysis of adaptation in a plantbreeding programmer. Aust. J. Agric. Res., 14: 742-754.

Fischer, R.A. (1984). Physiological limitations to producing wheat in semitropical and tropical environments and possible selection criteria. In wheat for more tropical environments. Proc. Int. Symp. 24-28 Sept. CIMMYT, Mexico City, Pp. 209-230.

Gomez, K.A and A.A. Gomez (1984). Statistical Procedures for Agriculture Research. John Willy and Sons.Inc. New York, USA.

Hamam, K.A and A.G.A. Khaled (2009). Stability of Wheat Genotypes under Different Environments and Their Evaluation under Sowing Dates and Nitrogen Fertilizer Levels. Aust. J. Basic and Applied Sci., 3: 206-217.

Hays, D.B; J.H. Do; R.E. Mason; G. Morgan and S.A. Finlayson (2007). Heat stress induced ethylene production in developing wheat grains induces kernel abortion and increased maturation in a susceptible cultivar. Plant Sci., 172: 1113-1123.

Hebert, Y; C. Plomion and N. Harzic (1995). Genotypic x environment interaction for root traits in maize as analysed with factorial regression models. Euphytica, 81: 85-92.

Hunt, L.A; G. Van der Poorten and S. Pararajasingham (1991). Post anthesis temperature effects on duration and rate of grain filling in some winter and spring wheats. Can. J. Plant Sci., 71: 609-617.

Jalaluddin, M.D and S.A. Harrison (1993). Repeatability of stability estimators for grain yield in wheat. Crop Sci., 33: 720-725.

Jatimliansky, J.R and F.J. Babinec (1984). Relationships between photosynthesis and canopy traits in flint type maize. Maize Genetics Cooperation Newsletter, 58: 117-118.

Joppa, L.R; K.L. Lebsock and R.H. Busch (1971). Yield stability of selected spring wheat cultivars (Triticum aestivum L.) in the Uniform Regional Nurseries 1959 to 1968. Crop Sci., 11: 238-241.

Kheiralla, K.A; M.A. El-Morshidy; M.H. Motawea and A.A. Saeid (2004). Performance and stability of some wheat genotypes under normal and water stress condition. Assiut J. of Agric. Sci., 35: 74 - 94.

Kumari, M; V.P. Singh; R. Tripathi and A.K. Joshi (2007). Variation for staygreen trait and its association with canopy temperature depression and yield traits under terminal heat stress in wheat. Buck HT, Nisi JE, Salomón N. Wheat Production in Stressed Environments: Proceedings of the $7^{\text {th }}$ International Wheat Conference, 27 November-2 December 2005, Mar del Plata, Argentina. 
Li, G; J. Zhang; C. Yang; Y. Song; C. Zheng; S. Wang; Z. Liu and Z. Ding (2014). Optimal yield-related attributes of irrigated rice for high yield potential based on path analysis and stability analysis. The Crop J., 2: 235-243.

Lobell, D.B; M.B. Burke; C. Tebaldi; M.D. Mastrandrea; W.P. Falcon and R.L. Naylor (2008). Prioritizing climate change adaptation needs for food security in 2030. Science, 319: 607-610.

Mahak, S; R.L. Srivastava and R.K. Dixit (2002). Stability analysis for certain advanced lines of bread wheat under rainfed condition. Adv. Plant Sci., 15: $295-300$.

Mahmoud, A.M. (2006). Genotype x Environment interactions of some bread wheat Genotypes (Triticum aestivum L.). Assiut J. of Agric. Sci., 37: 119-138.

Mason, R.E; S. Mondal; F.W. Beecher; A. Pacheco; B. Jampala; A.M.H. Ibrahim and D.B Hays (2010). QTL associated with heat susceptibility index in wheat (Triticum aestivum L.) under short-term reproductive stage heat stress. Euphytica, 174: 23-436.

Menshawy, A.M.M. (2007). Evaluation of some early bread wheat genotypes under different sowing dates: 1. Earliness characters. Egypt J. Plant Breed., 11: 25-40.

Mondal, S.K and M.R. Khajuria (2002). Stability analysis in bread wheat (Triticum asetvium L.). Envir. Ecol., 20: 620 - 624.

Mondal, S; R.P. Singh; J. Crossa; J. Huerta-Espino and I. Sharma (2013). Earliness in wheat: A key to adaptation under terminal and continual high temperature stress in South Asia. Field Crops Res., 151: 19-26.

MSTATC. (1990). A Microcomputer program for the design. Management and analysis of agronomic research experiments. Michigan State Univ.

Musich, J.T and D.A. Dusek (1980). Planting date and water deficit effects on development and yield of irrigated winter wheat. Agron. J., 72: 45-53.

Nachit, M.M and H. Ketata (1987). Selection for heat in durum wheat ( $T$. turgidum L. var. durum). Proc. Inter. Symp. On improving winter cereals under temperature and salinity. Spain, Pp. 26-29.

Randall, P.J and H.J. Moss (1990). Some effects of temperature regime during grain-filling on wheat quality. Aust. J. Agric. Res., 41:603 - 617.

Reynolds, M.P; M. Balota; M.I.B. Delgado; J. Amani and R.A. Fischer (1994). Physiological and morphological traits associated with spring wheat yield under hot irrigated conditions. Aust. J. Plant Physiol., 2: 717-730.

Rondanini, D.P; N.V. Gomez; M.B. Agosti and D.J. Miralles (2012). Global trends of rapeseed grain yield stability and rapeseed-to-wheat yield ratio in the last four decades. Europ. J. Agron., 37: 56-65.

Rosenow, D.T; J.E. Quisenberry; C.W. Wendt and L.E. Clark (1983) Drought tolerant sorghum and cotton germplasm. Agr. Water Manage., 7: 207222.

Rosenzweig, $\mathrm{N}$ and C.F. Tubiello (1996). Effects of changes in minimum and maximum temperature on wheat yields in the central U.S.A. simulation study. Agric. Meteorol., 80: 215-230. 
Royo, C; D. Villegas; Y. Rharrabti; R. Blanco; V. Martos and L.F. Garcia del Moral (2006). Grain growth and yield formation of durum wheat grown at contrasting latitudes and water regimes in a Mediterranean environment. Cereal Res. Commun., 34: 1021-1028.

Saadalla, M.M. (1993). Rate and duration of grain fill as affected by heat stress in spring wheat. Alex. J. Agric. Res., 38: 123-138.

Schulthess, A; I. Matus and A.R. Schwember (2013). Genotypic and environmental factors and their interactions determine semolina color of elite genotypes of durum wheat (Triticum turgidum L. var. durum) grown in different environments of Chile. Field Crop. Res., 149: 234244.

Sharma, R.C; A.K. Tiwary and G. Ortiz-Ferrara (2008). Reduction in kernel weight as apotential indirect selection criterion for wheat grain yield under terminal heat stress. Plant Breeding, 127: 241-248.

SPPS. (1995). Computer user's guide SPPS In, USA.

Sivori, Z. (1975) Planting time and vegetative period of wheat.c.f. field Crop Abstr., 28: 2959.

Tawfelis, M.B. (2006) Stability parameters of some bread wheat genotypes (Triticum aestivum L.) in new and old lands under Upper Egypt. Egypt J. Plant Breed., 10: 223-246.

Tesemma, T; S. Tsegaye; G. Belay; E. Bechere and D. Mitiku (1998). Stability of performance of tetraploid wheat landraces in Ethiopian highland. Euphytica, 102: 301-308.

Wardlaw, I.F; C. Blumenthal; O. Larroque and C.W. Wrigley (2002). Contrasting effects of chronic heat stress and heat shock on grain weight and flour quality in wheat. Funct. Plant Biol., 29: 25-34.

Yang, J; R.G. Sears; B.S. Gill and G.M. Paulsen (2002) Genotypic differences in utilization of assimilate sources during maturation of wheat under chronic heat and heat shock stresses. Euphytica, 125: 179-188. 


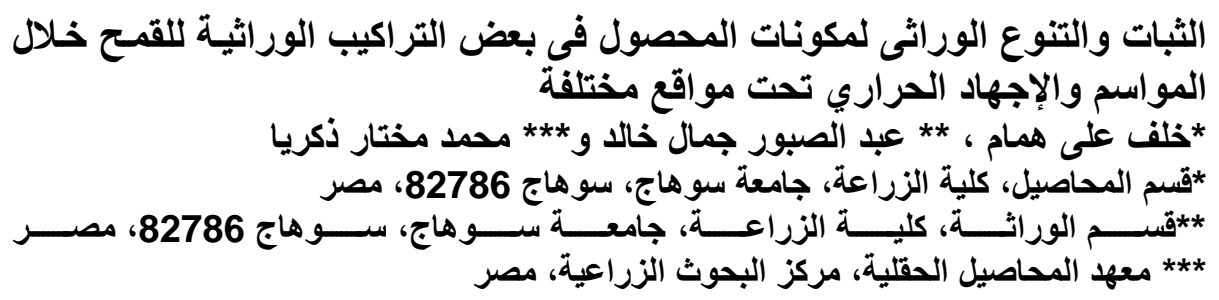

الثبات والتنوع الوراثى من العو امل الرئيسية لتحسين كثير من نباتات المحاصيل. حيث يتمثل

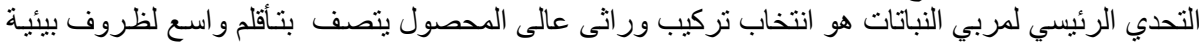

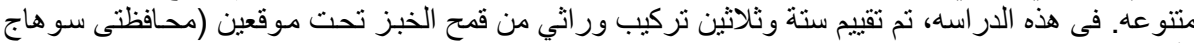

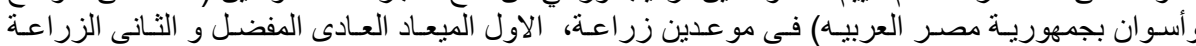

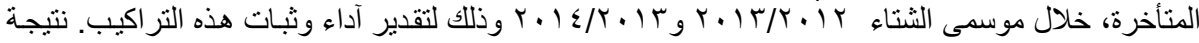

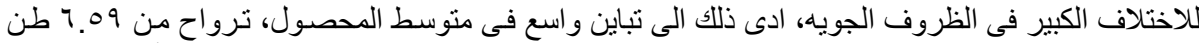

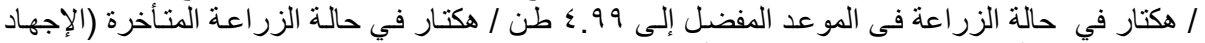

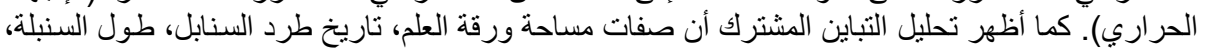

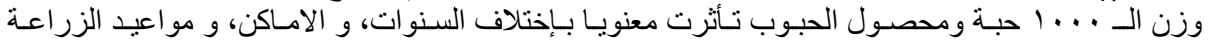

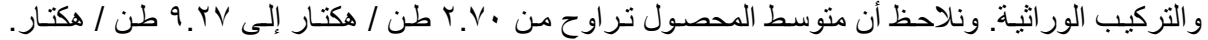

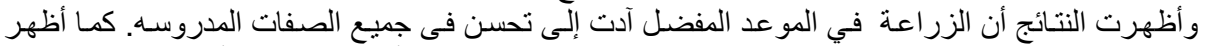

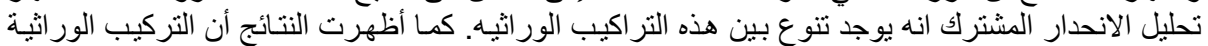

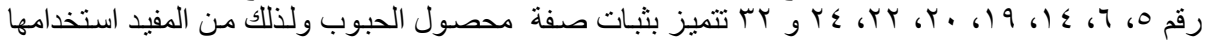

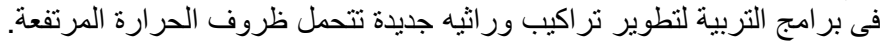

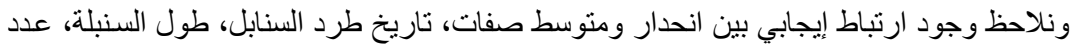

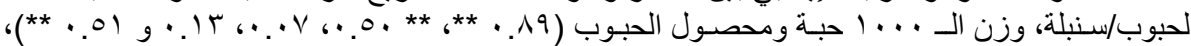

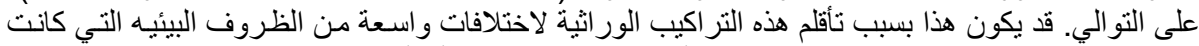

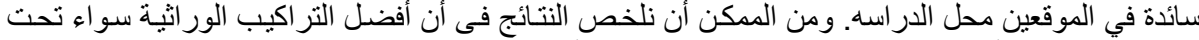

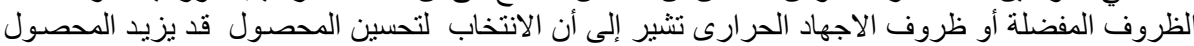
فى مدى و اسع من الظروف البيئية. 
Table 1: Pedigree of the studied wheat genotypes

\begin{tabular}{|c|c|c|}
\hline $\begin{array}{l}\text { Genotype } \\
\text { No. }\end{array}$ & Pedigree & Origin \\
\hline 1 & BECARD/5/KAUZ//ALTAR 84/AOS/3/MILAN/KAUZ/4/HUITĚS & CIMMYT \\
\hline 2 & ROLF07*2/5/REH/HARE//2*BCN/3/CROC_1/AE.SQUARROSA (213)//PGO/4/HUITES & CIMMYT \\
\hline 3 & TACUPETO F2001/BRAMBLING*2/5/KAUZ//ALTAR 84/AOS/3/MILAN/KAUZ/4/HUITES-1 & CIMMYT \\
\hline 4 & TACUPETO F2001/BRAMBLING*2/5/KAUZ//ALTAR 84/AOS/3/MILAN/KAUZ/4/HUITES-2 & CIMMYT \\
\hline 5 & BAV92//IRENA/KAUZ/3/HUITES*2/4/CROC_1/AE.SQUARROSA (224)//KULIN/3/WESTONIA-1 & CIMMYT \\
\hline 6 & BAV92//IRENA/KAUZ/3/HUITES*2/4/CROC_1/AE.SQUARROSA (224)//KULIN/3/WESTONIA-2 & CIMMYT \\
\hline 7 & BAV92//IRENA/KAUZ/3/HUITES*2/4/CROC 1/AE.SQUARROSA (224)//KULIN/3/WESTONIA-3 & CIMMYT \\
\hline 8 & BAV92//IRENA/KAUZ/3/HUITES*2/4/CROC_1/AE.SQUARROSA (224)//KULIN/3/WESTONIA-4 & CIMMYT \\
\hline 9 & BECARD/5/PGO//CROC_1/AE.SQUARROSA (224)/3/2*BORL95/4/CIRCUS & CIMMYT \\
\hline 10 & WBLL1*2/KURUKU//HEILO & CIMMYT \\
\hline 11 & $\begin{array}{l}\text { KAUZ//ALTAR 84/AOS/3/MILAN/KAUZ/4/HUITES/5/CROC_1/AE.SQUARROSA } \\
\text { (205)//KAUZ/3/SASIA/6/KAUZ//ALTAR 84/AOS/3/MILAN/KAUZ/4/HUITES }\end{array}$ & CIMMYT \\
\hline & CAL/NH//H567.71/3/SERI/4/CAL/NH//H567.71/5/2*KAUZ/6/PASTOR*2/7 & \\
\hline 12 & /CNDO/R143//ENTE/MEXI_2/3/AEGILOPS SQUARROSA (TAUS)/4/WEAVER/5/2*PASTOR & CIMMYT \\
\hline 13 & BAV92//IRENA/KAUZ/3/HUITES*2/4/GONDO/TNMU-1 & CIMMYT \\
\hline 14 & BAV92//IRENA/KAUZ/3/HUITES*2/4/GONDO/TNMU-2 & CIMMYT \\
\hline 15 & PFAU/WEAVER ${ }^{\star 2 / / B R A M B L I N G / 3 / Q U A I U ~}$ & CIMMYT \\
\hline 16 & MILAN/S87230//BAV92/5/PGO//CROC 1/AE.SQUARROSA (224)/3/2*BORL95/4/CIRCUS & CIMMYT \\
\hline 17 & WBLL1*2/KKTS//KBIRD & CIMMYT \\
\hline 18 & REH/HARE//2*BCN/3/CROC_1/AE.SQUARROSA (213)//PGO/4/HUITES/5/PVN & CIMMYT \\
\hline 19 & KBIRD//INQALAB 91*2/TUKURU-1 & CIMMYT \\
\hline 20 & KBIRD//INQALAB 91*2/TUKURU-2 & CIMMYT \\
\hline 21 & PBW343*2/KUKUNA/3/PGO/SERI//BAV92 & CIMMYT \\
\hline 22 & CHEN/AE.SQ/MEAVER/3/SSERI1/4/TOBA97/PASTOR/5/MUU \#1 & CIMMYT \\
\hline 23 & MUU \#1/7/CAL/NH//H567.71/3/SERI/4/CAL/NH//H567.71/5/2*KAUZ/6/PASTOR/8/MUU & CIMMYT \\
\hline 24 & UP2338*2/VIVITSI/3/FRET2/TUKURU//FRET2/4/OASIS/SKAUZ//4*BCN/3/2*PASTOR & CIMMYT \\
\hline 25 & $\mathrm{PBW}_{4} 3^{*} 2 / \mathrm{KUKUNA}^{*} 2 / / \mathrm{FRTL} / \mathrm{PIFED}-1$ & CIMMYT \\
\hline 26 & PBW343*2/KUKUNA ${ }^{\star} 2 / /$ FRTL/PIFED-2 & CIMMYT \\
\hline 27 & PBW343*2/KUKUNA*2//FRTL/PIFED-3 & CIMMYT \\
\hline 28 & CNO79//PF70354/MUS/3/PASTOR/4/BAV92*2/5/FH6-1-7-1 & CIMMYT \\
\hline 29 & CNO79//PF70354/MUS/3/PASTOR/4/BAV92*2/5/FH6-1-7-2 & CIMMYT \\
\hline 30 & CNO79//PF70354/MUS/3/PASTOR/4/BAV92²/5/FH6-1-7-3 & CIMMYT \\
\hline 31 & CNO79//PF70354/MUS/3/PASTOR/4/BAV92*2/5/FH6-1-7-4 & CIMMYT \\
\hline 32 & UP2338*2/KKTS*2/YYNAC & CIMMYT \\
\hline 33 & WBLL1*2/4/BABAX/LR42//BABAX/3/BABAX/LR42//BABAX-1 & CIMMYT \\
\hline 34 & WBLL1*2/4/BABAX/LR42//BABAX/3/BABAX/LR42//BABAX-2 & CIMMYT \\
\hline 35 & Sides 12 & Egypt \\
\hline 36 & Egypt 1 & Egypt \\
\hline
\end{tabular}


Hamam, K. A. et al.

Table 6: Genotypes means (G) at two locations (L) and two sowing date (D) for plant spike length and number of kernels over two years.

\begin{tabular}{|c|c|c|c|c|c|c|c|c|c|c|}
\hline \multirow{3}{*}{$\begin{array}{l}\text { Genotype } \\
\text { No. }\end{array}$} & \multicolumn{5}{|c|}{ Spike length $(\mathrm{cm})$} & \multicolumn{5}{|c|}{ Number of kernels/spike } \\
\hline & \multicolumn{2}{|c|}{ L1 } & \multicolumn{2}{|c|}{ L2 } & \multirow{2}{*}{ Mean } & \multicolumn{2}{|c|}{ L1 } & \multicolumn{2}{|c|}{$\mathrm{L} 2$} & \multirow[b]{2}{*}{ Mean } \\
\hline & D1 & D2 & D1 & D2 & & D1 & D2 & D1 & D2 & \\
\hline 1 & 13.48 & 11.76 & 13.02 & 11.36 & 12.41 & 60.29 & 50.43 & 59.03 & 49.43 & 54.80 \\
\hline 2 & 11.75 & 10.11 & 11.34 & 9.77 & 10.74 & 60.02 & 50.21 & 58.77 & 49.21 & 54.55 \\
\hline 3 & 14.06 & 12.31 & 13.58 & 11.89 & 12.96 & 50.14 & 41.94 & 49.09 & 41.10 & 45.57 \\
\hline 4 & 14.10 & 12.35 & 13.61 & 11.93 & 13.00 & 54.35 & 45.46 & 53.21 & 44.56 & 49.40 \\
\hline 5 & 11.75 & 10.12 & 11.35 & 9.77 & 10.75 & 62.24 & 50.53 & 60.92 & 49.53 & 55.81 \\
\hline 6 & 12.42 & 10.76 & 11.99 & 10.39 & 11.39 & 53.83 & 42.72 & 52.69 & 41.88 & 47.78 \\
\hline 7 & 11.67 & 10.04 & 11.27 & 9.69 & 10.67 & 52.30 & 43.76 & 51.19 & 42.88 & 47.53 \\
\hline 8 & 11.76 & 10.13 & 11.36 & 9.78 & 10.76 & 43.81 & 32.13 & 42.83 & 31.49 & 37.57 \\
\hline 9 & 11.10 & 9.49 & 10.71 & 9.16 & 10.12 & 34.23 & 28.63 & 33.51 & 28.05 & 31.11 \\
\hline 10 & 13.55 & 11.83 & 13.08 & 11.43 & 12.47 & 54.53 & 45.62 & 53.39 & 44.72 & 49.57 \\
\hline 11 & 11.81 & 10.18 & 11.41 & 9.84 & 10.81 & 54.71 & 45.78 & 53.57 & 44.88 & 49.74 \\
\hline 12 & 13.49 & 11.77 & 13.03 & $\begin{array}{l}11.37 \\
\end{array}$ & 12.42 & 50.40 & 41.63 & 49.34 & 40.80 & 45.54 \\
\hline 13 & 11.05 & 9.44 & 10.67 & 9.12 & 10.07 & 56.51 & 47.25 & 55.31 & 46.29 & 51.34 \\
\hline 14 & 12.90 & 11.21 & 12.46 & 10.83 & 11.85 & 48.57 & 40.63 & 47.55 & 39.82 & 44.14 \\
\hline 15 & 11.14 & 9.53 & 10.76 & 9.21 & 10.16 & 48.96 & 40.95 & 47.93 & 40.13 & 44.49 \\
\hline 16 & 11.13 & 9.52 & 10.75 & 9.20 & 10.15 & 43.65 & 36.51 & 42.73 & 35.78 & 39.67 \\
\hline \begin{tabular}{|l|}
17 \\
\end{tabular} & 11.24 & 9.64 & 10.86 & 9.32 & 10.27 & 43.79 & 36.64 & 42.88 & 35.92 & 39.81 \\
\hline 18 & 16.49 & 14.63 & 15.93 & 14.13 & 15.30 & 73.66 & 61.63 & 72.12 & 60.41 & 66.96 \\
\hline 19 & 9.47 & 7.91 & 9.14 & 7.63 & 8.54 & 41.96 & 29.24 & 40.94 & 28.73 & 35.22 \\
\hline 20 & 11.94 & 10.16 & 11.53 & 9.81 & 10.86 & 53.11 & 41.82 & 51.97 & 40.99 & 46.97 \\
\hline 21 & 10.37 & 8.47 & 10.01 & 8.18 & 9.26 & 52.45 & 43.88 & 51.36 & 43.01 & 47.68 \\
\hline 22 & 12.98 & 11.29 & 12.54 & 10.91 & 11.93 & 55.88 & 46.76 & 54.72 & 45.84 & 50.80 \\
\hline 23 & 13.58 & 11.86 & 13.11 & 11.46 & 12.50 & 68.14 & 57.01 & 66.72 & 55.89 & 61.94 \\
\hline 24 & 11.26 & 9.66 & 10.88 & 9.33 & 10.28 & 52.48 & 43.92 & 51.40 & 43.07 & 47.72 \\
\hline 25 & 11.74 & 10.10 & 11.34 & 9.76 & 10.74 & 47.82 & 40.00 & 46.81 & 39.20 & 43.46 \\
\hline 26 & 10.94 & 9.32 & 10.56 & 9.00 & 9.96 & 37.21 & 31.09 & 36.40 & 30.45 & 33.79 \\
\hline 27 & 11.72 & 10.09 & 11.32 & 9.74 & 10.72 & 41.67 & 34.85 & 40.79 & 34.16 & 37.87 \\
\hline 28 & 12.99 & 11.30 & 12.54 & 10.92 & 11.94 & 51.01 & 42.68 & 49.95 & 41.84 & 46.37 \\
\hline 29 & 14.78 & 13.01 & 14.28 & 12.57 & 13.66 & 51.51 & 43.10 & 50.45 & 42.26 & 46.83 \\
\hline 30 & 14.05 & 12.29 & 13.56 & 11.88 & 12.95 & 60.17 & 50.33 & 58.90 & 49.32 & 54.68 \\
\hline 31 & 11.90 & 10.11 & 11.49 & 9.77 & 10.82 & 44.93 & 25.11 & 43.67 & 24.67 & 34.60 \\
\hline 32 & 14.14 & 12.39 & 13.66 & 11.97 & 13.04 & 50.89 & 42.58 & 49.83 & 41.74 & 46.26 \\
\hline
\end{tabular}


J. Plant Production, Mansoura Univ., Vol. 6 (3), March, 2015

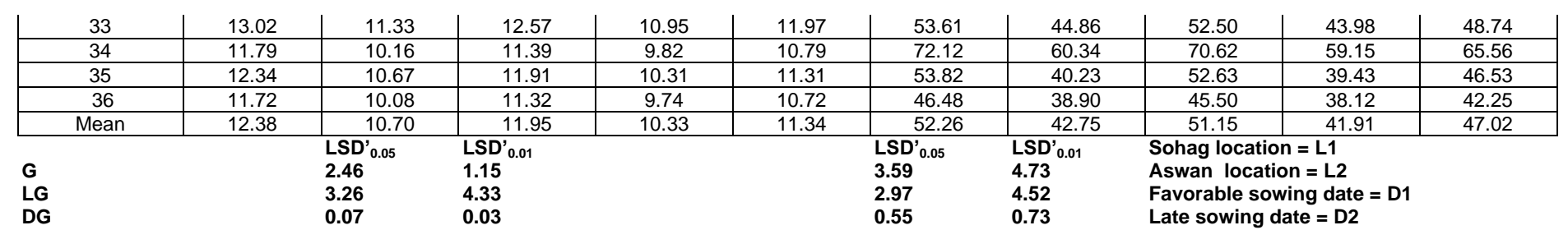


Hamam, K. A. et al. 
J. Plant Production, Mansoura Univ., Vol. 6 (3): 349 -370, 2015

Table 9: Genotypes average performance over 6 environments and stability parameters of the thirty six wheat genotypes for flag leaf area, days to heading and spike length.

\begin{tabular}{|c|c|c|c|c|c|c|c|c|c|}
\hline \multirow{2}{*}{$\begin{array}{c}\text { Genotype } \\
\text { No. }\end{array}$} & \multicolumn{3}{|c|}{ Flag leaf area $(\mathrm{cm})$} & \multicolumn{3}{|c|}{ Days to heading } & \multicolumn{3}{|c|}{ Spike length $(\mathrm{cm})$} \\
\hline & $\bar{x}$ & bi & $S^{2} d_{i}$ & $\bar{x}$ & bi & $S^{2} d_{i}$ & $\bar{x}$ & $b_{i}$ & $S^{2} d_{i}$ \\
\hline 1 & 22.69 & $1.19^{*}$ & 0.000 & 84.89 & 0.96 & $0.71^{\star \star}$ & 12.41 & 1.04 & 0.000 \\
\hline 2 & 14.07 & $0.65^{\star}$ & 0.000 & 87.50 & 1.03 & 0.00 & 10.74 & 0.97 & 0.000 \\
\hline 3 & 18.23 & 0.99 & 0.000 & 86.92 & 0.97 & $1.77^{\star \star}$ & 12.96 & 1.06 & 0.000 \\
\hline 4 & 19.07 & $0.88^{*}$ & 0.000 & 87.02 & 1.04 & $0.46^{* \star}$ & 13.00 & 1.05 & 0.000 \\
\hline 5 & 19.58 & $0.88^{*}$ & 0.000 & 88.60 & 1.10 & $21.07^{\star \star}$ & 10.75 & 0.97 & 0.000 \\
\hline 6 & 29.40 & $0.75^{\star}$ & $0.006^{\star \star}$ & 88.56 & 1.07 & $1.72^{\star \star}$ & 11.39 & 0.96 & 0.000 \\
\hline 7 & 21.29 & $1.44^{\star}$ & $0.005^{\star \star}$ & 89.13 & 1.12 & $44.76^{\star \star}$ & 10.67 & 1.00 & 0.000 \\
\hline 8 & 22.01 & $0.95^{\star}$ & 0.000 & 89.16 & 1.14 & $167.18^{\star \star}$ & 10.75 & 0.97 & 0.000 \\
\hline 9 & 18.30 & $1.21^{*}$ & 0.003 & 87.02 & 1.04 & $0.46^{\star \star}$ & 10.11 & 0.98 & 0.000 \\
\hline 10 & 24.94 & $0.94^{*}$ & 0.000 & 85.36 & 0.94 & $4.62^{* \star}$ & 12.47 & 1.00 & 0.000 \\
\hline 11 & 25.05 & $0.73^{*}$ & 0.002 & 84.41 & 0.97 & $0.02^{* \star}$ & 10.81 & 0.95 & 0.000 \\
\hline 12 & 24.42 & $1.26^{*}$ & 0.000 & 87.02 & 1.04 & $0.46^{* \star}$ & 12.41 & 1.04 & 0.000 \\
\hline 13 & 19.37 & $1.56^{*}$ & $0.023^{\star \star}$ & 86.53 & 1.05 & $3.61^{\star \star}$ & 10.07 & 0.99 & $0.001^{\star \star}$ \\
\hline 14 & 21.16 & $1.09^{\star}$ & 0.000 & 88.02 & 1.05 & $0.25^{\star *}$ & 11.85 & 1.02 & 0.000 \\
\hline 15 & 28.30 & $1.49^{\star}$ & 0.000 & 87.02 & 1.04 & $0.46^{\star \star}$ & 10.16 & 0.96 & 0.000 \\
\hline 16 & 20.27 & $1.13^{*}$ & 0.000 & 85.36 & 0.94 & $4.62^{* \star}$ & 10.15 & 0.97 & 0.000 \\
\hline 17 & 25.65 & $0.60^{*}$ & $0.006^{\star \star}$ & 85.42 & 0.98 & $0.06^{* *}$ & 10.26 & $0.92^{*}$ & 0.000 \\
\hline 18 & 27.39 & 1.02 & 0.000 & 87.50 & 1.03 & 0.00 & 15.30 & 1.10 & $0.006^{\star *}$ \\
\hline 19 & 23.67 & $0.93^{*}$ & 0.000 & 87.55 & 1.06 & $2.53^{\star \star}$ & 8.54 & 0.92 & $0.001^{\star \star}$ \\
\hline 20 & $\begin{array}{l}19.98 \\
\end{array}$ & $0.74^{\star}$ & 0.000 & 85.36 & 0.94 & $4.62^{\star \star}$ & $\begin{array}{l}10.86 \\
\end{array}$ & $1.05^{\star}$ & 0.000 \\
\hline 21 & 20.54 & $0.81^{*}$ & 0.000 & 86.38 & 0.95 & $6.25^{\star \star}$ & 9.26 & 1.11 & 0.000 \\
\hline 22 & 22.37 & $0.70^{*}$ & 0.000 & 84.83 & 0.92 & $12.89^{\star \star}$ & 11.93 & 0.99 & 0.000 \\
\hline 23 & 22.54 & $0.69^{*}$ & 0.001 & 83.33 & 0.97 & $2.31^{* \star}$ & 12.50 & 1.00 & 0.000 \\
\hline 24 & 22.86 & $0.42^{*}$ & $0.008^{\star \star}$ & 82.18 & 0.85 & $86.68^{\star \star}$ & 10.28 & 0.92 & 0.000 \\
\hline 25 & 26.40 & $1.28^{\star}$ & 0.000 & 80.07 & 0.80 & $203.06^{\star \star}$ & 10.74 & 0.98 & 0.000 \\
\hline 26 & 15.29 & $1.87^{\star}$ & $0.397^{\star \star}$ & 85.84 & 0.93 & $16.32^{\star \star}$ & 9.96 & 1.04 & $0.008^{\star \star}$ \\
\hline 27 & 25.25 & $1.35^{\star}$ & 0.000 & 86.38 & 0.95 & $6.25^{\star \star}$ & 10.72 & 0.98 & 0.000 \\
\hline 28 & 27.47 & $0.83^{*}$ & 0.002 & 84.83 & 0.92 & $12.89^{\star \star}$ & 11.94 & 0.98 & 0.000 \\
\hline 29 & 27.72 & $0.71^{*}$ & $0.005^{\star \star}$ & 89.13 & 1.12 & $44.76^{\star \star}$ & 13.66 & 1.03 & $0.003^{\star *}$ \\
\hline 30 & 17.52 & 1.02 & 0.000 & 86.53 & 1.05 & $3.61^{* *}$ & 12.95 & 1.07 & 0.000 \\
\hline 31 & 21.15 & 1.01 & 0.000 & 86.44 & 0.98 & $0.14^{\star \star}$ & 10.82 & $1.06^{\star}$ & 0.000 \\
\hline 32 & 24.21 & $0.87^{\star}$ & 0.000 & 84.89 & 0.96 & $0.71^{\star *}$ & 13.04 & 1.03 & 0.000 \\
\hline 33 & 26.56 & $0.62^{*}$ & $0.006^{* \star}$ & 93.23 & 1.18 & $95.06^{* \star}$ & 11.97 & 0.97 & 0.000 \\
\hline 34 & 26.26 & $0.90^{*}$ & 0.000 & 86.53 & 1.05 & $3.61^{* *}$ & 10.79 & $0.96^{*}$ & 0.000 \\
\hline 35 & 26.23 & $1.21^{*}$ & 0.000 & 85.47 & 1.01 & $0.06^{* *}$ & 11.31 & $0.99^{*}$ & 0.000 \\
\hline 36 & 24.42 & $1.31^{*}$ & $0.012^{\star \star}$ & 83.85 & 1.03 & $3.13^{* *}$ & 10.67 & 1.05 & 0.000 \\
\hline Mean & 22.82 & & & 86.34 & & & 11.34 & & \\
\hline $\mathrm{r}(\bar{x}, \mathrm{bi})$ & \multicolumn{3}{|c|}{-0.17} & \multicolumn{3}{|c|}{$0.89^{\star \star}$} & \multicolumn{3}{|c|}{$0.50^{\star \star}$} \\
\hline
\end{tabular}


Table 7: Genotypes means (G) at two locations (L) and two sowing date (D) for and 1000-Kernel weight and grain yield over two years.

\begin{tabular}{|c|c|c|c|c|c|c|c|c|c|c|}
\hline \multirow{3}{*}{$\begin{array}{c}\text { Genotype } \\
\text { No. }\end{array}$} & \multicolumn{5}{|c|}{ 1000-Kernel weight (g.) } & \multicolumn{5}{|c|}{ Grain yield (ton/ht.) } \\
\hline & \multicolumn{2}{|c|}{ L1 } & \multicolumn{2}{|c|}{ L2 } & \multirow[b]{2}{*}{ Mean } & \multicolumn{2}{|c|}{ L1 } & \multicolumn{2}{|c|}{ L2 } & \multirow[b]{2}{*}{ Mean } \\
\hline & D1 & D2 & D1 & D2 & & D1 & D2 & D1 & D2 & \\
\hline 1 & 45.37 & 32.76 & 43.96 & 31.76 & 38.46 & 4.61 & 3.76 & 4.48 & 3.65 & 4.13 \\
\hline 2 & 50.93 & 37.35 & 49.36 & 36.21 & 43.46 & 9.27 & 6.72 & 9.04 & 6.53 & 7.89 \\
\hline 3 & 51.78 & 38.05 & 50.18 & 36.89 & 44.23 & 8.36 & 6.32 & 8.16 & 6.16 & 7.25 \\
\hline 4 & 50.24 & 36.77 & 48.69 & 35.65 & 42.84 & 6.97 & 4.69 & 6.79 & 4.57 & 5.76 \\
\hline 5 & 52.95 & 39.01 & 51.32 & 37.82 & 45.28 & 6.28 & 4.46 & 6.11 & 4.34 & 5.30 \\
\hline 6 & 64.96 & 48.91 & 62.98 & 47.45 & 56.08 & 7.41 & 6.20 & 7.21 & 6.04 & 6.72 \\
\hline 7 & 49.93 & 36.52 & 48.38 & 35.40 & 42.56 & 5.51 & 4.25 & 5.37 & 4.15 & 4.82 \\
\hline 8 & 61.53 & 46.08 & 59.64 & 44.69 & 52.99 & 4.31 & 3.84 & 4.19 & 3.73 & 4.02 \\
\hline 9 & 57.53 & 42.78 & 55.75 & 41.48 & 49.39 & 4.40 & 3.99 & 4.28 & 3.87 & 4.14 \\
\hline 10 & 48.07 & 29.18 & 46.52 & 28.29 & 38.02 & 4.22 & 3.63 & 4.11 & 3.53 & 3.87 \\
\hline 11 & 52.60 & 38.72 & 50.99 & 37.55 & 44.97 & 6.75 & 4.51 & 6.58 & 4.41 & 5.56 \\
\hline 12 & 48.50 & 35.34 & 47.00 & 34.26 & 41.28 & 4.67 & 3.14 & 4.53 & 3.05 & 3.85 \\
\hline 13 & 40.33 & 23.63 & 39.00 & 22.88 & 31.46 & 7.39 & 5.75 & 7.19 & 5.57 & 6.48 \\
\hline 14 & 60.38 & 45.13 & 58.52 & 43.76 & 51.95 & 8.90 & 7.09 & 8.67 & 6.90 & 7.89 \\
\hline 15 & 51.03 & 34.43 & 49.41 & 33.38 & 42.06 & 4.32 & 3.49 & 4.20 & 3.40 & 3.85 \\
\hline 16 & 57.99 & 43.16 & 56.20 & 41.84 & 49.80 & 4.34 & 3.12 & 4.22 & 3.04 & 3.68 \\
\hline 17 & 52.67 & 36.05 & 51.03 & 34.96 & 43.68 & 4.32 & 3.14 & 4.21 & 3.06 & 3.68 \\
\hline 18 & 40.43 & 38.83 & 39.24 & 37.66 & 39.04 & 8.62 & 5.56 & 8.40 & 5.42 & 7.00 \\
\hline
\end{tabular}


J. Plant Production, Mansoura Univ., Vol. 6 (3), March, 2015

\begin{tabular}{|c|c|c|c|c|c|c|c|c|c|c|}
\hline 19 & 65.99 & 49.76 & 63.97 & 48.26 & 57.00 & 8.62 & 7.40 & 8.38 & 7.20 & 7.90 \\
\hline 20 & 40.94 & 27.86 & 39.66 & 27.01 & 33.87 & 6.87 & 5.02 & 6.70 & 4.89 & 5.87 \\
\hline 21 & 43.71 & 30.56 & 42.35 & 29.62 & 36.56 & 8.70 & 6.29 & 8.49 & 6.14 & 7.41 \\
\hline 22 & 62.60 & 46.97 & 60.69 & 45.56 & 53.96 & 8.89 & 7.83 & 8.66 & 7.62 & 8.25 \\
\hline 23 & 56.46 & 41.90 & 54.74 & 40.64 & 48.44 & 9.00 & 6.88 & 8.77 & 6.67 & 7.83 \\
\hline 24 & 41.87 & 29.88 & 40.59 & 28.97 & 35.33 & 7.19 & 4.86 & 7.00 & 4.73 & 5.95 \\
\hline 25 & 51.52 & 37.83 & 49.93 & 36.68 & 43.99 & 6.48 & 4.93 & 6.29 & 4.81 & 5.63 \\
\hline 26 & 47.42 & 34.46 & 45.92 & 33.38 & 40.30 & 4.64 & 3.55 & 4.51 & 3.45 & 4.04 \\
\hline 27 & 59.12 & 46.50 & 57.32 & 45.10 & 52.01 & 4.49 & 3.12 & 4.37 & 3.03 & 3.75 \\
\hline 28 & 50.96 & 37.37 & 49.40 & 36.24 & 43.49 & 6.29 & 4.47 & 6.12 & 4.36 & 5.31 \\
\hline 29 & 42.88 & 30.53 & 41.57 & 29.61 & 36.15 & 9.00 & 6.52 & 8.78 & 6.35 & 7.66 \\
\hline 30 & 54.69 & 42.84 & 53.02 & 41.54 & 48.02 & 4.60 & 2.78 & 4.47 & 2.70 & 3.64 \\
\hline 31 & 65.11 & 53.58 & 63.14 & 51.97 & 58.45 & 8.34 & 7.47 & 8.14 & 7.28 & 7.81 \\
\hline 32 & 56.38 & 43.14 & 54.67 & 41.84 & 49.01 & 7.41 & 5.84 & 7.21 & 5.67 & 6.53 \\
\hline 33 & 61.10 & 45.73 & 59.24 & 44.36 & 52.61 & 5.87 & 4.74 & 5.70 & 4.60 & 5.23 \\
\hline 34 & 55.44 & 41.06 & 53.74 & 39.82 & 47.52 & 8.83 & 5.92 & 8.63 & 5.77 & 7.29 \\
\hline 35 & 54.02 & 38.16 & 52.34 & 37.00 & 45.38 & 7.13 & 5.39 & 6.26 & 4.76 & 5.89 \\
\hline 36 & 57.47 & 42.73 & 55.70 & 41.44 & 49.34 & 8.04 & 5.87 & 7.17 & 5.24 & 6.58 \\
\hline Mean & 52.91 & 38.99 & 51.28 & 37.80 & 45.25 & 6.70 & 5.07 & 6.48 & 4.91 & 5.79 \\
\hline $\begin{array}{l}\text { LG } \\
D G\end{array}$ & $\begin{array}{l}\text { LSD' }^{\prime} \\
2.98 \\
2.78 \\
0.58\end{array}$ & $\begin{array}{l}\text { LSD' } \\
3.93 \\
4.83 \\
0.76\end{array}$ & & & $\begin{array}{l}\text { LSD' }^{\prime} \\
0.87 \\
10.00 \\
0.18\end{array}$ & $\begin{array}{l}\text { LSD' } \\
1.14 \\
17.35 \\
0.24\end{array}$ & $\begin{array}{l}\text { Soh } \\
\text { Asv } \\
\text { Fav } \\
\text { Lat }\end{array}$ & $\begin{array}{l}\text { e sov } \\
\text { ing od }\end{array}$ & $\begin{array}{l}\text { L1 } \\
=\text { L2 } \\
\text { date } \\
=\text { D2 }\end{array}$ & \\
\hline
\end{tabular}


Hamam, K. A. et al. 